\title{
Impact of COVID-19 lockdown on acute pediatric antipsychotic poisoning outcome in Tanta University Poison Control Centre
}

\author{
Nadia E Helal ${ }^{1}$, Elsayed I. Elgebally ${ }^{2}$ and Dina E. Elgameel ${ }^{1}$
}

1 Department of Forensic Medicine and Clinical Toxicology, Faculty of Medicine, Tanta University, Tanta, Egypt.* Poison control centre, Aseer, Saudi Arabia.

2 Department of Pediatrics, Faculty of Medicine, Menoufia University, Shebeen Al-kom, Egypt. Pediatric department, Saudi German Hospital, Aseer, Saudi Arabia

\begin{abstract}
Background: Acute pediatric antipsychotic poisoning has obviously increased during COVID-19 lockdown. Minimal research concerning this topic were conducted in Egypt.

Objectives: to identify the outcome predictors of acute pediatric antipsychotics poisoning during COVID 19 lockdown.

Methods: The study was carried on children with acute antipsychotics poisoning admitted to Tanta University Poison Control center from (2019-2020). Recorded data were obtained from patients' files including sociodemographic characteristics, clinical examination, results of laboratory investigations, and ECG in addition to severity assessment by poison severity score.

Results: A noticeable increase in the overall number of antipsychotic poisoned children was observed in 2020 than 2019. Additionally, the ingested doses, suicidal rates and the mean delay time were increased in 2020. Lower GCS ranging from 3-8 and 9-12 were more observed in 2020 compared to 2019. Atypical agents with minimal extrapyramidal manifestations were more commonly ingested. Hypotension and ECG changes particularly sinus tachycardia and prolonged QTc intervals were common in the studied sample and observed frequently in 2020 than 2019 cases. ICU admission rate together with hemodynamic instability increased in 2020 than that in 2019 however the length of hospital stay was nearly equal. Logistic regression analysis revealed that lower GCS and higher PSS were significantly accompanied by increased the likelihood of ICU admission.

Conclusion: Severity of antipsychotic poisoning was higher during COVID-19 lockdown. Predictors of worse outcomes regarding ICU admission rates, neurological and cardiovascular toxicities were concluded.
\end{abstract}

Key words Antipsychotics, pediatric, poisoning, outcome, COVID-19

\section{Introduction}

$\mathrm{D}$ rug ingestion is the commonest cause of acute poisoning among children according to poison control centers records all over the world. A great percent of hospital admission cases involves drug poisoning, particularly with psychotropic drugs such as sedatives, antidepressants, and neuroleptics (Watson et al., 2004; Gummin et al., 2017; Mubarak et al., 2019).

Antipsychotics are primarily used for management of various psychotic disorders including schizophrenia and manic phase of bipolar disorders. Meanwhile, they are also used as antiemetic, and in management of many neurological diseases (chorea, dystonia, and tics) and headache (Georgiev et al., 2015).

Antipsychotics are classified as "typical" or "atypical." They are also classified by their chemical structure as first-generation, including butyrophenones (droperidol, haloperidol) and phenothiazines (chlorpromazine, promethazine), and second generation such as olanzapine, risperidone, quetiapine, and more recently ziprasidone and aripiprazole. The second generation of antipsychotics became the mainstay of treatment of schizophrenia with a superior efficacy versus the first-generation agents (Ngo et al., 2008).
The "atypical," or second-generation agents, are known to have fewer extrapyramidal manifestations at appropriate doses. That is referred to its lower binding affinity to the D2 receptors (Kapur and Seeman, 2000; Ngo et al., 2008).

Despite its safer profile regarding endocrinal and motor side effects, both typical and atypical antipsychotics have unique receptor-binding profiles of each agent. For example, some atypical antipsychotics have alpha 1-adrenergic blockage (risperidone, olanzapine, quetiapine, and aripiprazole), which may cause orthostatic hypotension. Some antagonize central and peripheral muscarinic receptors (clozapine, olanzapine, quetiapine), which may result in sedation, sinus tachycardia and urine retention (DuBois, 2005 and Kumra et al., 2008).

Conclusively, acute antipsychotic toxicity affects multiple organ systems. The most serious are the cardiovascular and the central nervous systems with concern to additional unique drugs profiles (DuBois, 2005).

During COVID-19 lockdown period, worldwide dramatic behavioral changes occurred. This influenced all ages and a resultant increase in admission rates of 
poison control centers was unexpectedly faced (Kampf et al., 2020).

To our knowledge, research done on pediatric population regarding acute antipsychotic toxicity is relatively deficient. Potential effects on multiple organ systems need to be considered in overdosed children. This study spots the light on the outcome predictors in acutely antipsychotic intoxicated children during the period of COVID-19 lockdown.

\section{Patients and Methods}

This retrospective comparative cross-sectional observational study was performed in Tanta University Poison Control Center (TUPCC) using the data of two years interval (from the start of 2019 to the end of 2020). Data was obtained from the archived clinical files after approval of the Head of TUPCC. The confidentiality of data was maintained using coding numbers. The present study was carried out in accordance with the World Medical Association Declaration of Helsinki, following approval of the research ethics committee, Faculty of Medicine, Tanta University, Egypt (approval number: 34399/1/21).

All symptomatic pediatric $(<18$ years $)$ patients of both sexes who were diagnosed as acute antipsychotic poisoning during the study period were enrolled. The severity of neurological, cardiovascular, and respiratory manifestations as well as any metabolic disturbances were assessed on admission according to the standardized Poisoning Severity Score (PSS) according to Persson et al. (1998). The enrolled patients were further subdivided into two groups according to whether they were admitted to TUPCC in 2019 (pre-covid year) or in 2020 (covid-19 year).

Patients with reported history of co-ingestions, chronic poisoning, chronic illness (as diabetes mellitus, hypertension, or cardiac disease), drug addiction or whose data were incomplete were excluded.

Methods:

For all cases, sociodemographic history including age, sex and residence and past medical history were recorded. This was in addition to the reported toxicological history including manner of poisoning, name of antipsychotic agent, type whether typical or atypical, its form, route of intake, total amount of drug taken, and time passed from intake till hospital admission. The available data about neurological examination including presence of extrapyramidal manifestations, abnormal movements and slurred speech, assessment of pupil size and reaction, vital parameters and level of consciousness using Glasgow coma scale (GCS) were also recorded. In addition, results of laboratory investigations including arterial blood gases, electrolytes (sodium, and potassium), liver enzymes, creatinine, urea, complete blood count, random blood sugar and electrocardiogram abnormalities were obtained from medical records.

Outcome measures were recorded and compared in both groups including primary outcome which is the mode of discharge from hospital whether improvement or complications. While secondary outcomes included the need for intubation and intensive care unit admission and length of hospital stay.

Statistical analysis was performed using SPSS version 21. Quantitative parametric data were presented by mean \pm standard deviation, range and evaluated by Student's t test. While non-parametric data were presented by mean \pm standard deviation, median and interquartile range (IQR) and evaluated by Mann-Whitney test (U) (Gunarto., 2019).

Categorical data were presented by number and percent and assessed by the chi-square test and when it was inappropriate it was replaced by Monte Carlo Exact test. Spearman correlation was done for the linear relation between non-parametric variables. Logistic regression analyses were performed to study the relation between variables as predictors for the outcome (ICU admission). The $\mathrm{P}$ value was considered significant at the level of $\leq 0.05$ and highly significant at the level of $<0.001$.

\section{Results}

In the current study, Table (1) shows that 126 pediatric patients were diagnosed as acute antipsychotic poisoning and admitted in TUPCC from the start of 2019 to end of 2020. About 56 of them were in the pre-covid year 2019, while the 70 were in the covid year 2020 representing (44.4\% and 55.5\% respectively). Most of the studied antipsychotic poisoned cases were preschool females below 6 years of age. No significant differences could be detected between the studied patients in 2019 and 2020 regarding their socio-demographic figures including age, gender, and residence ( $\mathrm{p}>0.05$, each).

The ingested dose showed a significant increase in 2020 with a mean of $(144.7 \pm 200.5)$ compared to 2019 (90.2 \pm 179.01$)$. Regarding the class of ingested antipsychotic agent, typical antipsychotics represented $19.6 \%$ and $25 \%$ of the studied cases in 2019 and 2020, respectively. However, atypical antipsychotics were $80.4 \%$ of cases in 2019 and $74.3 \%$ of cases in 2020 .

There was an observed increase in the consumption of antipsychotic medications as a way of suicide in pediatrics in 2020 compared to 2019 (35.7\% and $28.6 \%$ respectively), although this was statistically insignificant. Among those who committed suicide in 2020 , four cases were psychiatric patients who consumed their own antipsychotic medications, while only one psychiatric teenage female committed suicide with her own treatment in 2019. However, the drug belonged to a family member in the remaining suicidal cases.

There was insignificant difference between the studied patients in both years as regards the typology of agent ingested with resperidone $(30.4 \%)$ being the commonest ingested one in 2019 , followed by clozapex $(23.2 \%)$ then haloperidol $(14.3 \%)$. Whereas, in 2020; both resperidone and clozapex were equally consumed $(28.6 \%$, each), followed by haloperidol (14.3\%) (p $>0.05)$.

There was a significant increase in the meantime elapsed between antipsychotic agent ingestion and receiving in-hospital treatment in 2020

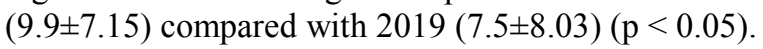


Table (2) demonstrates the clinical characteristics of the studied patients, no significant differences were noted between the patients in 2019 and 2020 regarding the presenting signs and symptoms, prehospital management, GCS, and pupil size. Patients manifested by deep coma with GCS ranging from 3-8, were more frequently traced among 2020 patients than 2019 ones (11.4\% and $7.1 \%$ respectively). Likewise, patients in 2020 had a range of 9-12 more frequently than 2019 (22.9\% and $19.6 \%$ respectively). Similarly, constricted pupils were noticed in (39.3\%) among 2019 cases and in $(48.6 \%)$ of 2020 cases.

Concerning vital data in the studied patients, the mean pulse rate showed significant increase among 2020 cases than $2019(127.1 \pm 17.92$ and $117.0 \pm 25.85$ respectively) ( $\mathrm{p}<0.05)$. On the other hand, systolic (SBP) and diastolic blood pressure (DBP) showed a significant decrease among 2020 cases in comparison to $2019(83.4 \pm 12.26$ and $105 \pm 16.1$ respectively) for SBP and $(58.3 \pm 9.48$ and $63.1 \pm 11.38$ respectively) for DBP $(\mathrm{p}<0.05)$. Another significant decrease was recorded in respiratory rate which had a mean of $23.6 \pm 5.35$ among 2019 cases and $13.4 \pm 1.8$ among 2020 cases $(p<0.05)$. However, temperature, and oxygen saturation records were very close in the two years with no noticeable statistical difference between both groups $(p>0.05)$.

By application of PSS, moderate severity was found in lower rates $(28.6 \%)$ during 2019 compared to $(34.3 \%)$ in 2020. Similarly, severe scores were recorded in lower rates in $2019(8.9 \%)$ than in $(18.6 \%)$ of 2020 cases. However, this was statistically insignificant (Table 2).

Concerning laboratory findings, no significant differences could be traced between the studied patients in 2019 and 2020 regarding routine laboratory investigations: random blood glucose, ALT, AST, creatinine, urea, $\mathrm{Na}, \mathrm{K}$, and all arterial blood gases parameters $(p>0.05)$. Conversely, there was a significant increase in WBCs counts among cases in 2020 compared to $2019(\mathrm{P}<0.05)$.
Regarding ECG records, most patients in both years had normal ECG. However, sinus tachycardia was more often among cases in 2020 compared to those in 2019. Likewise, prolonged QTc interval showed an increase in $2020(17.1 \%)$ compared to 2019 $(14.3 \%)$, however insignificant $(\mathrm{p}>0.05)$. On the other hand, mean QTc interval in 2020 was $410.3 \pm 40.43$ with a significant increase compared to 2019 (391.1 \pm 35.70) $(\mathrm{p}<0.05)($ Table 3$)$

Outcome characteristics were evaluated revealing that, those who needed intubation and ICU admission were more frequently reported in 2020 compared to 2019 (17.1\% and $10.7 \%$ respectively). No cases developed hemodynamic instability in 2019 , but it occurred in (12.9\%) among 2020 cases revealing a significant increase. However, the mean hospital stay in hours was nearly equal in both years $(p>0.05)$. Most of the studied patients in the present study improved with no statistically significant difference between the two groups (Table 4).

Logistic regression analysis was performed to assess the likelihood factors that may affect the probability of ICU admission and /or intubation in the Corona year 2020 in acute pediatric antipsychotic poisoning. These potential factors involved the amount of drug ingested, delay time since admission in hours, on admission PSS and GCS.

Increase in PSS and GCS were significant independent predictors of ICU admission. Increase in PSS was significantly associated with increased likelihood of ICU admission (OR: $0.055,95 \%$ CI: 0.010 to $0.313, p=$ $0.001)$. Decrease GCS was significantly associated with increased likelihood of ICU admission (OR: 0.227, 95\% CI: 0.052 to $0.990, p=0.048$ ) (Table 5).

There was a significant positive moderate correlation between QTc prolongation and the ingested dose, as well as the PSS (Figure 1, 3), whereas a weak negative insignificant correlation was noticed between QTe prolongation and GCS (Figure 2). 
Table (1): Sociodemographic and toxicological characteristics of the studied patients (total $N=26$ )

\begin{tabular}{|c|c|c|c|c|c|c|c|}
\hline \multicolumn{2}{|c|}{ Characteristics } & \multicolumn{2}{|c|}{ Year $2019(\mathrm{~N}=56)$} & \multicolumn{2}{|c|}{ Year $2020(N=70)$} & Test statistic & P value \\
\hline \multirow{3}{*}{$\begin{array}{c}\text { Age } \\
\text { (Years) }\end{array}$} & 0-6 years & 31 & $55.4 \%$ & 32 & $45.7 \%$ & \multirow{3}{*}{$\begin{array}{c}\chi^{2} \\
1.591\end{array}$} & \multirow{3}{*}{0.451} \\
\hline & $>6-12$ years & 12 & $21.4 \%$ & 15 & $21.4 \%$ & & \\
\hline & $>12-18$ years & 13 & $23.2 \%$ & 23 & $32.9 \%$ & & \\
\hline \multirow{2}{*}{ Gender } & Female & 29 & $51.8 \%$ & 46 & $65.7 \%$ & \multirow{2}{*}{$2.505 \chi^{2}$} & \multirow{2}{*}{0.113} \\
\hline & Male & 27 & $48.2 \%$ & 24 & $34.3 \%$ & & \\
\hline \multirow{2}{*}{ Residence } & Rural & 23 & $39.9 \%$ & 23 & $32.9 \%$ & \multirow{2}{*}{$0.560 \chi^{2}$} & \multirow{2}{*}{0.454} \\
\hline & Urban & 34 & $60.7 \%$ & 47 & $67.1 \%$ & & \\
\hline \multirow{2}{*}{ Co-morbidities } & Absent & 44 & $78.6 \%$ & 50 & $71.4 \%$ & \multirow{2}{*}{$0.838 \chi^{2}$} & \multirow{2}{*}{0.360} \\
\hline & Present & 12 & $21.4 \%$ & 20 & $28.6 \%$ & & \\
\hline Amount (mg) & Mean \pm SD & \multicolumn{2}{|c|}{$90.2 \pm 179.01$} & \multicolumn{2}{|c|}{$144.7 \pm 200.5$} & $1074.0 \mathrm{U}$ & $0.007 *$ \\
\hline \multirow{2}{*}{ Typical or atypical } & Typical & 11 & $19.6 \%$ & 18 & $25.7 \%$ & \multirow{2}{*}{$0.647 \chi^{2}$} & \multirow{2}{*}{0.421} \\
\hline & Atypical & 45 & $80.4 \%$ & 52 & $74.3 \%$ & & \\
\hline \multirow{2}{*}{ Form } & Liquid & 10 & $17.9 \%$ & 17 & $24.3 \%$ & \multirow{2}{*}{$0.764 \chi^{2}$} & \multirow{2}{*}{0.382} \\
\hline & Tablet & 46 & $82.1 \%$ & 53 & $75.7 \%$ & & \\
\hline \multirow{3}{*}{$\begin{array}{l}\text { Manner of } \\
\text { Poisoning }\end{array}$} & Suicidal & 16 & $28.6 \%$ & 25 & $35.7 \%$ & \multirow{3}{*}{$1.091 \chi^{2}$} & \multirow{3}{*}{0.580} \\
\hline & Accidental & 34 & $60.7 \%$ & 36 & $51.4 \%$ & & \\
\hline & Iatrogenic & 6 & $10.7 \%$ & 9 & $12.9 \%$ & & \\
\hline \multirow{8}{*}{$\begin{array}{l}\text { Antipsychotic } \\
\text { agent name }\end{array}$} & Risperidone & 17 & $30.4 \%$ & 20 & $28.6 \%$ & \multirow{8}{*}{$4.253 \mathrm{MC}$} & \multirow{8}{*}{0.770} \\
\hline & Neurazine & 3 & $5.4 \%$ & 8 & $11.4 \%$ & & \\
\hline & Clozapex & 13 & $23.2 \%$ & 20 & $28.6 \%$ & & \\
\hline & Haloperidol & 8 & $14.3 \%$ & 10 & $14.3 \%$ & & \\
\hline & Triflouroperazine & 2 & $3.6 \%$ & 3 & $4.3 \%$ & & \\
\hline & Quietiapine & 5 & $8.9 \%$ & 5 & $7.1 \%$ & & \\
\hline & Olanzepine & 6 & $10.7 \%$ & 3 & $4.3 \%$ & & \\
\hline & Amipride & 2 & $3.6 \%$ & 1 & $1.4 \%$ & & \\
\hline Delay time (hours) & Mean \pm SD & \multicolumn{2}{|c|}{$7.5 \pm 8.03$} & \multicolumn{2}{|c|}{$\frac{1}{9.9 \pm 7.15}$} & $1234.0 \mathrm{U}$ & $0.004 *$ \\
\hline
\end{tabular}


Table (2): Clinical and severity characteristics of the studied patients (total $N=126$ )

\begin{tabular}{|c|c|c|c|c|c|c|c|}
\hline \multicolumn{2}{|c|}{ Variable } & \multicolumn{2}{|c|}{$\begin{array}{c}\text { Year 2019 } \\
(\mathrm{N}=56) \\
\end{array}$} & \multicolumn{2}{|c|}{$\begin{array}{c}\text { Year 2020 } \\
(\mathbf{N}=70) \\
\end{array}$} & $\begin{array}{c}\text { Test } \\
\text { statistic }\end{array}$ & $P$ value \\
\hline \multirow{7}{*}{$\begin{array}{l}\text { Antipsychotic } \\
\text { agent name }\end{array}$} & Asymptomatic & 12 & $16.4 \%$ & 14 & $15.7 \%$ & & \\
\hline & Vomiting & 2 & $2.8 \%$ & 3 & $3.4 \%$ & & \\
\hline & Slurred speech & 8 & $11 \%$ & 11 & $12.4 \%$ & & \\
\hline & Drowsiness & 16 & $21.9 \%$ & 25 & $28.1 \%$ & & \\
\hline & Seizures & 4 & $5.5 \%$ & 3 & $3.4 \%$ & & \\
\hline & $\begin{array}{c}\text { Extrapyramidal } \\
\text { manifestations }\end{array}$ & 12 & $16.4 \%$ & 22 & $24.7 \%$ & & \\
\hline & $\begin{array}{c}\text { Disturbed } \\
\text { consciousness }\end{array}$ & 19 & $26 \%$ & 11 & $12.4 \%$ & & \\
\hline \multirow{3}{*}{ Prehospital management } & No & 44 & $78.6 \%$ & 55 & $78.6 \%$ & \multirow{3}{*}{$0.767 \chi^{2}$} & \multirow{3}{*}{0.681} \\
\hline & Appropriate & 6 & $10.7 \%$ & 5 & $7.1 \%$ & & \\
\hline & Not appropriate & 6 & $10.7 \%$ & 10 & $14.3 \%$ & & \\
\hline \multirow{3}{*}{$\begin{array}{c}\text { GCS on } \\
\text { admission }\end{array}$} & $13-15$ & 41 & $73.2 \%$ & 46 & $65.7 \%$ & \multirow{3}{*}{$1.003 \chi^{2}$} & \multirow{3}{*}{0.605} \\
\hline & $9-12$ & 11 & $19.6 \%$ & 16 & $22.9 \%$ & & \\
\hline & $3-8$ & 4 & $7.1 \%$ & 8 & $11.4 \%$ & & \\
\hline \multirow{2}{*}{ Pupil } & Constricted & 22 & $39.3 \%$ & 34 & $4.6 \%$ & \multirow{2}{*}{$1.086 \chi^{2}$} & \multirow{2}{*}{0.297} \\
\hline & Normal & 34 & $60.7 \%$ & 36 & $51.4 \%$ & & \\
\hline $\begin{array}{c}\text { Pulse } \\
\end{array}$ & Mean \pm SD & \multicolumn{2}{|c|}{$117 \pm 25.89$} & \multicolumn{2}{|c|}{$127.1 \pm 17.92$} & $1375.5 \mathrm{U}$ & $0.004 *$ \\
\hline Systolic Blood Pressure & Mean \pm SD & \multicolumn{2}{|c|}{$105 \pm 16.1$} & \multicolumn{2}{|c|}{$83.4 \pm 18.26$} & $609 \mathrm{U}$ & $<0.004^{*}$ \\
\hline Diastolic Blood Pressure & Mean \pm SD & \multicolumn{2}{|c|}{$63.1 \pm 11.38$} & \multicolumn{2}{|c|}{$45.7 \pm 7.34$} & $386 \mathrm{U}$ & $<0.004^{*}$ \\
\hline Respiratory rate & Mean \pm SD & \multicolumn{2}{|c|}{$26.3 \pm 5.35$} & \multicolumn{2}{|c|}{$13.4 \pm 1.8$} & $28 \mathrm{U}$ & $<0.001^{*}$ \\
\hline Temperature & Mean \pm SD & \multicolumn{2}{|c|}{$36.9 \pm 0.32$} & \multicolumn{2}{|c|}{$36.9 \pm 0.44$} & $1860.5 \mathrm{U}$ & 0.605 \\
\hline Oxygen saturation & Mean \pm SD & \multicolumn{2}{|c|}{$97.8 \pm 2.01$} & \multicolumn{2}{|c|}{$97.6 \pm 1.66$} & $1747.5 \mathrm{U}$ & 0.284 \\
\hline \multirow{4}{*}{$\begin{array}{c}\text { Poison Severity Score } \\
\text { (PSS) }\end{array}$} & None $=0$ & 13 & $23.2 \%$ & 9 & $12.9 \%$ & \multirow{4}{*}{$4.469 \chi^{2}$} & \multirow{4}{*}{0.215} \\
\hline & Minor $=1$ & 22 & $39.3 \%$ & 24 & $34.3 \%$ & & \\
\hline & Moderate $=2$ & 16 & $28.6 \%$ & 24 & $34.3 \%$ & & \\
\hline & Severe $=3$ & 5 & $8.9 \%$ & 13 & $18.6 \%$ & & \\
\hline
\end{tabular}

$N=$ number; SD: standard deviation, $U:$ Mann-Whitney test $; \chi^{2}:$ chi-square test; SD: standard deviation; * significant at $p<0.05$.

Table (3): Laboratory and ECG characteristics of the studied patients (total $N=126$ )

\begin{tabular}{|c|c|c|c|c|c|c|c|}
\hline \multicolumn{2}{|c|}{ Variable } & \multirow{2}{*}{\multicolumn{2}{|c|}{$\begin{array}{c}\text { Year } 2019 \\
(\mathbf{N}=\mathbf{5 6}) \\
7.4 \pm 0.06\end{array}$}} & \multirow{2}{*}{\multicolumn{2}{|c|}{$\begin{array}{c}\begin{array}{c}\text { Year 2020 } \\
(\mathbf{N}=\mathbf{7 0})\end{array} \\
7.4 \pm 0.05 \\
\end{array}$}} & \multirow{2}{*}{$\begin{array}{c}\begin{array}{c}\text { Test } \\
\text { statistic }\end{array} \\
0.142 \mathrm{t} \\
\end{array}$} & \multirow{2}{*}{$\begin{array}{c}\text { P value } \\
0.887\end{array}$} \\
\hline $\mathbf{P H}$ & Mean \pm SD & & & & & & \\
\hline P CO2 & Mean \pm SD & \multicolumn{2}{|c|}{$36.8 \pm 6.21$} & \multicolumn{2}{|c|}{$36.5 \pm 6.06$} & $0.276 \mathrm{t}$ & 0.783 \\
\hline $\mathrm{HCO3}$ & Mean \pm SD & \multicolumn{2}{|c|}{$23.5 \pm 4.22$} & \multicolumn{2}{|c|}{$24.1 \pm 4.40$} & $1869.5 \mathrm{U}$ & 0.657 \\
\hline $\mathrm{Na}$ & Mean \pm SD & \multicolumn{2}{|c|}{$139.2 \pm 6.33$} & \multicolumn{2}{|c|}{$140.7 \pm 3.81$} & $1649.5 \mathrm{U}$ & 0.127 \\
\hline $\mathbf{K}$ & Mean \pm SD & \multicolumn{2}{|c|}{$3.9 \pm 0.47$} & \multicolumn{2}{|c|}{$3.8 \pm 0.54$} & $1.622 \mathrm{t}$ & 0.107 \\
\hline RBS & Mean \pm SD & \multicolumn{2}{|c|}{$113.4 \pm 32.81$} & \multicolumn{2}{|c|}{$112.6 \pm 24.68$} & $1892.5 \mathrm{U}$ & 0.740 \\
\hline WBCs & Mean \pm SD & \multicolumn{2}{|c|}{$6803.6 \pm 2205.7$} & \multicolumn{2}{|c|}{$8133.3 \pm 3251.64$} & $1398.5 \mathrm{U}$ & $0.008^{*}$ \\
\hline SGPT & Mean \pm SD & \multicolumn{2}{|c|}{$21.3 \pm 7.90$} & \multicolumn{2}{|c|}{$19.0 \pm 7.54$} & $1581.0 \mathrm{U}$ & 0.062 \\
\hline SGOT & Mean \pm SD & \multicolumn{2}{|c|}{$25.9 \pm 11.97$} & \multicolumn{2}{|c|}{$22.7 \pm 7.34$} & $1723.0 \mathrm{U}$ & 0.244 \\
\hline Creatinine & Mean \pm SD & \multicolumn{2}{|c|}{$0.7 \pm 0.35$} & \multicolumn{2}{|c|}{$0.8 \pm 0.27$} & $1723.5 \mathrm{U}$ & 0.243 \\
\hline Urea & Mean \pm SD & \multicolumn{2}{|c|}{$20.9 \pm 5.69$} & \multicolumn{2}{|c|}{$22.8 \pm 7.00$} & $1677.5 \mathrm{U}$ & 0.165 \\
\hline QTC (ms) & Mean \pm SD & \multicolumn{2}{|c|}{$391.1 \pm 35.70$} & \multicolumn{2}{|c|}{$410.3 \pm 40.43$} & $1176.50 \mathrm{U}$ & $<0.001 *$ \\
\hline \multirow{4}{*}{ ECG } & Normal ECG & 33 & $58.9 \%$ & 30 & $42.9 \%$ & \multirow{4}{*}{$4.948 \chi^{2}$} & \multirow{4}{*}{0.176} \\
\hline & Prolonged QTC & 8 & $14.3 \%$ & 12 & $17.1 \%$ & & \\
\hline & Sinus tachycardia & 15 & $26.8 \%$ & 25 & $35.7 \%$ & & \\
\hline & Wide QRS complex & 0 & $0.0 \%$ & 3 & $4.3 \%$ & & \\
\hline
\end{tabular}

$N=$ number; SD: standard deviation, $U:$ Mann-Whitney test; $\chi^{2}:$ chi-square test; SD: standard deviation; * significant at $p<0.05$. 
Table (4): Outcome and hospitalization period of the studied patients (total $N=126$ )

\begin{tabular}{|c|c|c|c|c|c|c|c|}
\hline \multicolumn{2}{|l|}{ Variable } & \multicolumn{2}{|c|}{$\begin{array}{c}\text { Year } 2019 \\
(N=56)\end{array}$} & \multicolumn{2}{|c|}{$\begin{array}{c}\text { Year 2020 } \\
(N=70)\end{array}$} & Test statistic & P value \\
\hline \multirow{2}{*}{ Discharge } & Improved & 41 & $73.2 \%$ & 59 & $84.3 \%$ & \multirow{2}{*}{$2.329 \chi^{2}$} & \multirow{2}{*}{0.127} \\
\hline & Complicated & 15 & $26.8 \%$ & 11 & $15.7 \%$ & & \\
\hline \multirow{2}{*}{ Intubation \& ICU admission } & Yes & 6 & $10.7 \%$ & 12 & $17.1 \%$ & \multirow[t]{2}{*}{$1.050 \chi^{2}$} & \multirow{2}{*}{0.306} \\
\hline & No & 50 & $89.3 \%$ & 58 & $82.9 \%$ & & \\
\hline \multirow{2}{*}{ Hemodynamic instability } & Yes & 0 & $0.00 \%$ & 9 & $12.9 \%$ & \multirow{2}{*}{$7.754 \chi^{2}$} & \multirow{2}{*}{$0.005^{*}$} \\
\hline & $\mathrm{NO}$ & 56 & $100 \%$ & 61 & $87.1 \%$ & & \\
\hline Hospital stay (hours) & Mean \pm SD & \multicolumn{2}{|c|}{$15.5 \pm 11.65$} & \multicolumn{2}{|c|}{$15.9 \pm 9.76$} & $1767.0 \mathrm{U}$ & 0.342 \\
\hline
\end{tabular}

$N=$ number; SD: standard deviation, U: Mann-Whitney test; $\chi 2:$ chi-square test; SD: standard deviation; * significant at $p<0.05$.

Table (5): Logistic regression analysis to assess likelihood of ICU admission in 2020 (Covid-19 year):

\begin{tabular}{|c|c|c|c|}
\hline Variable & OR & $\mathbf{9 5 \%}$ CI & P value \\
\hline On admission GCS & 0.227 & $0.052-0.990$ & $0.048^{*}$ \\
\hline On admission PSS & 0.055 & $0.010-0.313$ & $0.001 *$ \\
\hline
\end{tabular}

PSS: poison severity score; GCS: Glasgow coma scale, CI: confidence interval; OR: odds ratio; * significant at p<0.05

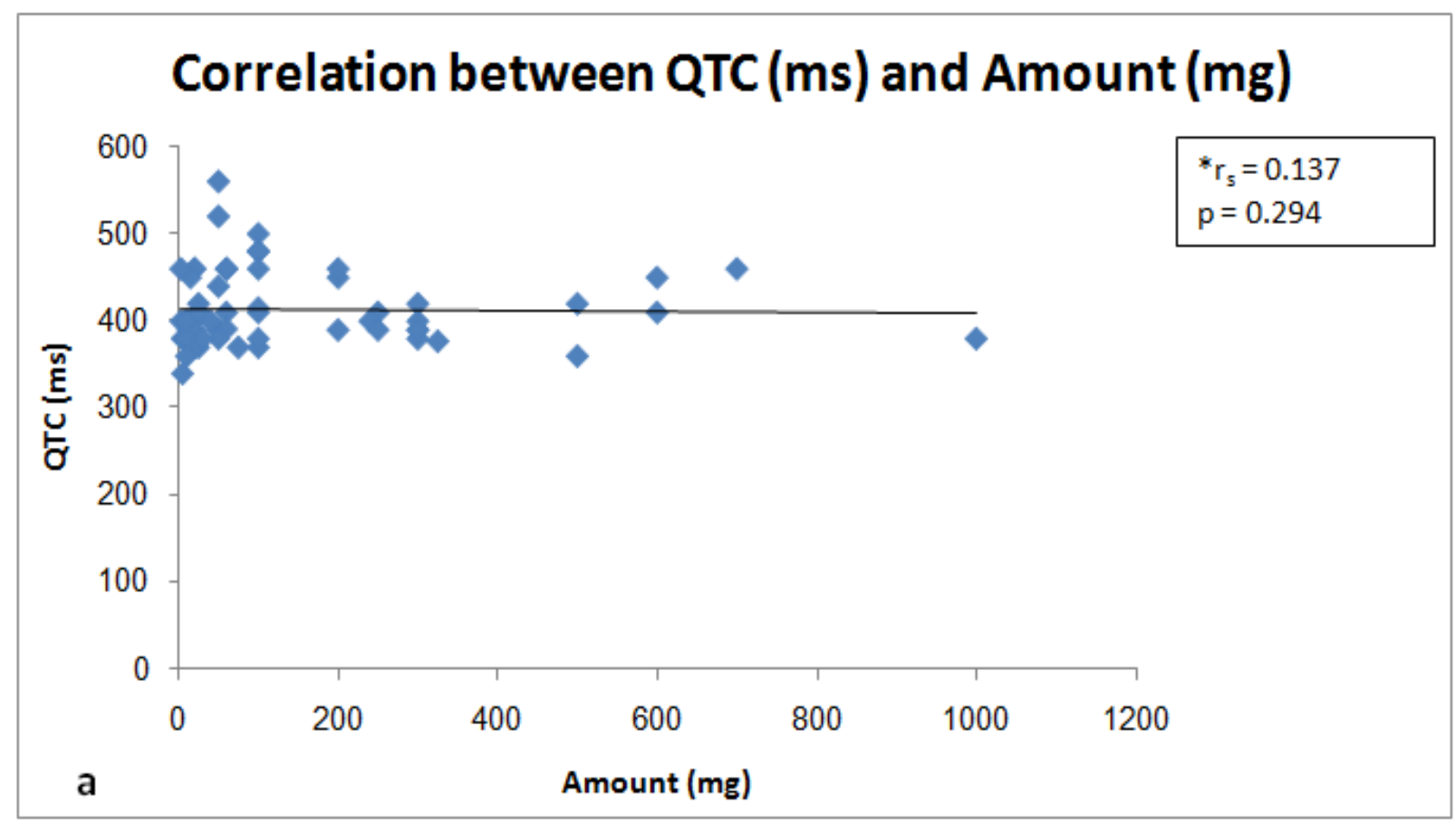

* $\mathbf{r}_{\mathrm{s}}$ (Spearman correlation)

Figure (1): Correlation between QTC and amount ingested in milligrams. 


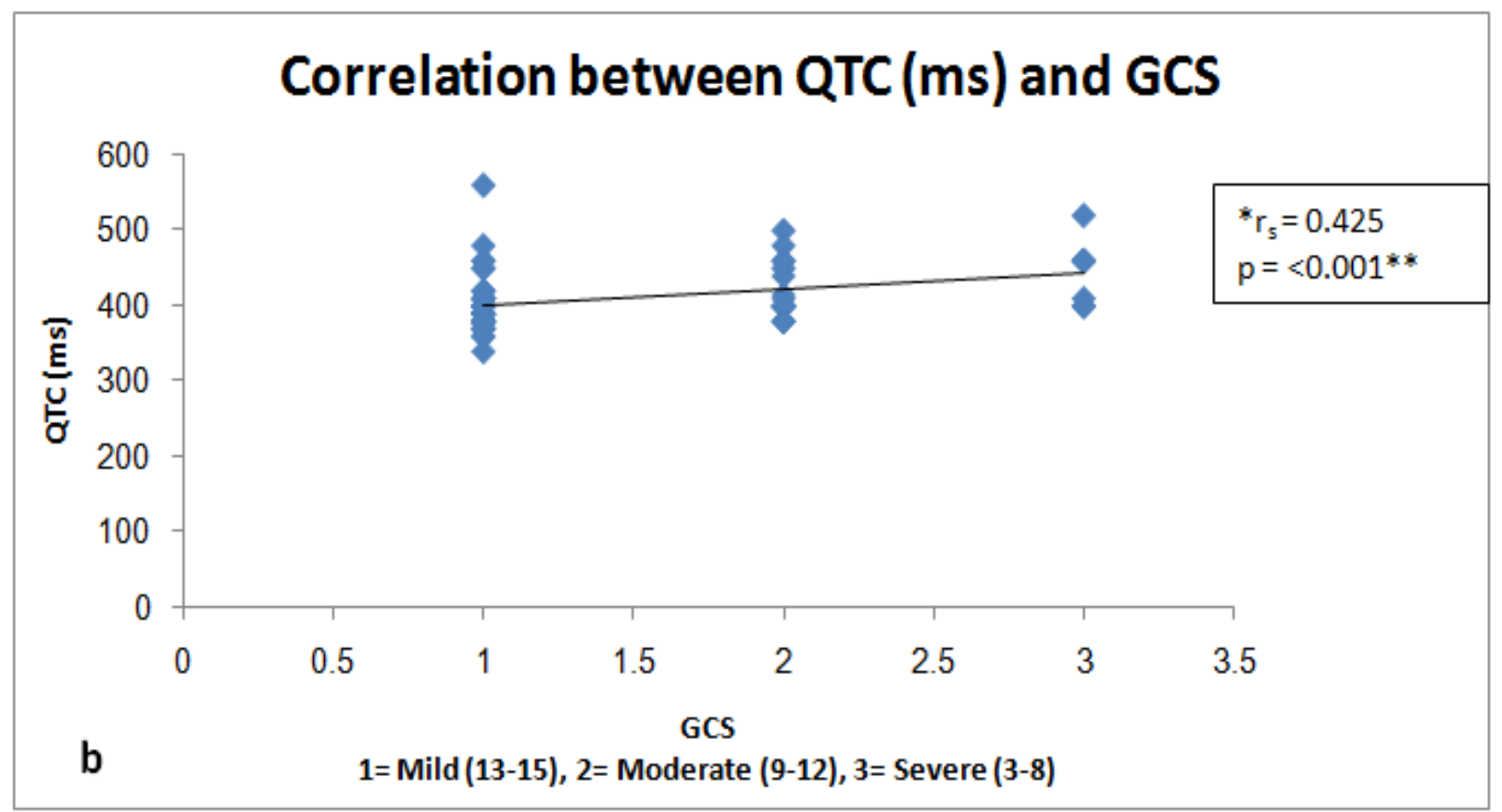

* $\mathbf{r}_{\mathrm{s}}$ (Spearman correlation), GCS: Glasgow coma scale

Figure (2): Correlation between QTC (ms) and GCS

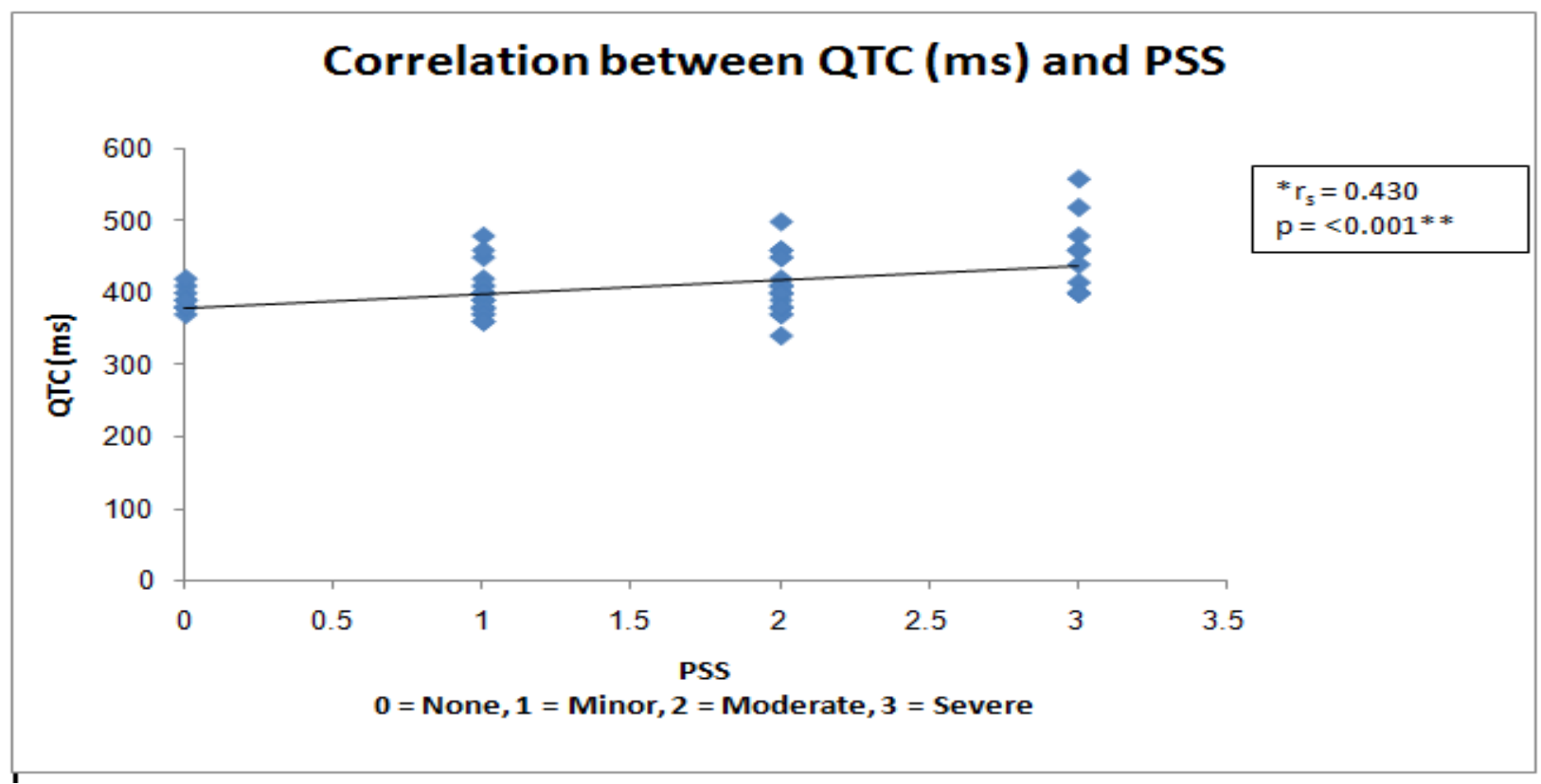

* $\mathbf{r}_{\mathrm{s}}$ (Spearman correlation) PSS: poison severity score

Figure (3): Correlation between QTC (ms) and PSS

\section{Discussion}

Antipsychotics poisoning is frequently reported as a significant cause of morbidity among children. Despite marked efforts exerted to decrease the burden of the problem as the use of child proof packages and parent education campaigns, it is still on the rise (). Furthermore, it increased worldwide in the last few years (Bond et al., 2012; Gummin et al., 2017).

During 2020 due to covid-19 pandemic, general public actions were tried including telework, closure of non-fundamental services, and even complete lockdown (Jin et al., 2020). In Egypt, a partial lockdown was implemented on March 12, with resultant serious economical and mental health consequences.

The typology of poisoning was completely reformed particularly to sedative hypnotics and antipsychotics that showed a noticeable elevation in TUPCC in comparison to the pre COVID-19 year, 2019 (Fayed and Sherif, 2021).

However, in Egypt there are statistical limitations related to this topic. Moreover, early prediction of the outcome of acute antipsychotic 
poisoning in TUPCC has many advantages. It may help us to predict the need for early intervention, ICU admission, close monitoring and/or increase duration of observation, early prediction of complications and proper management to reduce morbidity and mortality during the pandemic.

That is why the current study focused on assessing outcome predictors in acute pediatric antipsychotic poisoning in patients admitted to Tanta University Poison Control Unit during 2020 to assess the impact of COVID-19 lockdown on the outcome of acute pediatric antipsychotic poisoning compared with the pre covid year 2019 .

In the present study, the total number of antipsychotic poisoned pediatric patients rose in 2020 compared to 2019; this could be attributed to increased prescription of antipsychotics as treatment of anxiety and mood disorders suffered by the adult population during the lockdown. Another explanation is the possible increase in domestic troubles among parents which may result in less quality of care given to children. These factors led to increased home availability of antipsychotics and the likelihood for risky behaviors as trying parents' medications. Similarly, Meli et al. (2014) and Dayasiri et al. (2017) reported that pediatric antipsychotics toxicity obviously increased in the last period and was considered a significant reason of morbidity.

Regarding the ingested dose, a significant increase was noted in 2020 which could be linked to multiple factors recognized throughout COVID 19 lockdown such as emotional troubles, educational problems related to schools' closure, family conflicts and social media influence. Furthermore, closure of nurseries especially with lack or deficient supervision at home could play a role. Previous studies recorded lower doses of ingestion and subsequently lesser morbidity (Capel et al., 2000; Rasimas and Liebelt, 2012; Meli et al., 2014).

Atypical antipsychotics were ingested by most cases, which agrees with the results of Berling et al., (2016). This reflects more consumption of atypical group than typical ones owing to their lower adverse effects namely extrapyramidal manifestations (Ucok and Gaebel, 2008).

Suicidal attempts generally increased all over the world, in addition to psychological burden, emotional disturbance and behavioral changes that had been seen during the COVID 19 lockdown. All are factors that may clarify the higher suicidal rate recorded in this study. Similarly, Georgiev et al., (2015), Borg et al., (2016), Sheridan et al., (2017) noticed suicidal attempts by psychotropic drugs among teenagers.

In the present study, the mean time of delay was significantly prolonged in 2020 compared to 2019. These findings agreed with Fayed and Sharif, (2021) who reported a significant delay to reach TUPCC since ingestion. This can be explained by the quarantine which restricted hospital access. Additionally, the parents' phobias to acquire covid infection at hospital played a role in their hesitation to rush to the poison control center. This formed another obstacle that hindered timely access to the hospital (Roux and Tellier 2020).

In the current study, a small number of the studied cases developed low GCS; this agrees with previous studies who reported low severity and fatality of antipsychotic poisoning (Capel et al., 2000; Rasimas and Liebelt, 2012; Meli et al., 2014). The degree of CNS depression could be related to the drug receptor binding affinity (Sackey et al., 2017). Though insignificant, decreased consciousness according to GCS (in both ranges from 3-8 and from 9-12) was more common in 2020 admitted patients than 2019 . That may be explained by longer time delays between ingestion and admission to hospital in 2020 cases.

Extrapyramidal manifestations in the present study were minimal, which might be linked to ingestion of atypical antipsychotics more than typical ones; as it well known to have a safer profile regarding extrapyramidal manifestations owing to their lesser dopamine receptor binding affinity (Divac et al., 2014).

Hypotension was common in the studied sample; seen in 2020 cases more than 2019. This is contrast to other studies by Tan et al. (2009), Gugger (2011), Mucci et al. (2016), and Ramnarine (2017), who reported that blood pressure changes were not common. According to Muench and Hammer (2000), orthostatic hypotension can occur in all antipsychotics depending on the degree of $\alpha 1$ receptor antagonism especially with low potency typical antipsychotics as chlorpromazine and thioridazine. Additionally, it is reported with risperidone and quetiapine.

Regarding pulse, sinus tachycardia was significantly increased among 2020 cases. It is a common manifestation of antipsychotic poisoning (Pickford, 2000, Kramer et al., 2010). That is possibly explained by the variable receptor binding affinity of these drugs (Sackey et al., 2017).

Bradypnea was significantly reported in the current study, with more cases in 2020 than 2019. Respiratory depression is rare in antipsychotic poisoning, but it occurs with more frequency in children than adults (Ben-Noun et al., 2000; Akyol et al., 2005 ;Levine and Burns, 2007). On the other hand, Rasimas and Liebelt (2012) who stated that significant respiratory depression is not common with antipsychotics.

Poison severity score (PSS) application demonstrated that the severity of the admitted cases in 2020 increased compared to 2019. A point of view explaining the higher severity and morbidity during covid pandemic can be higher ingested doses and longer delay time.

This study showed that ECG changes as sinus tachycardia and prolonged QTc interval were more often noted among 2020 cases than 2019.These changes were commonly described among antipsychotic poisoned patients (Tan et al., 2009; Hammad et al.,2016). However, Chohan et al. (2015) reported that less incidence of QTc prolongation with atypical antipsychotics compared to typical group. No 
cases showed the rare condition of torsade de points, which agrees with Wenzel-Seifert et al. (2011).

In the present study, no significant differences could be detected among cases of the 2019 and 2020 regarding arterial blood gases. Conversely, Capel et al. (2000) reported different $\mathrm{ABG}$ disorders. This discrepancy could be caused by involvement of different classes of antipsychotics.

No significant differences were noticed throughout the study regarding random blood sugar, ALT, AST, urea, creatinine, and serum electrolytes. This is in contrast to Malik et al. (2005) who reported hypokalemia with risperidone and quetiapine poisoning. This may be related to inhibition of potassium efflux channels and blockade of potassium shifting from intracellular to extracellular space (Pal et al., 2015).

Significant leukocytosis was noted among 2020 cases more than 2019. The exact mechanism is still unclear; some antipsychotics provoke the release of various cytokines as TNF, IL-2, IL-6, and G-CSF (Fehsel et al., 2005). Another mechanism might be related to co-existence of illness.

The present study revealed that ICU admitted cases increased in 2020 in comparison to 2019.Additionally hemodynamic instability showed a significant increase during 2020 however, the length of hospital stay was nearly equal during the two years. This is unlike the results of Berling team who demonstrated a longer duration of hospital stay (Berling et al., 2016).

Most of the studied cases in the present study were improved and discharged after absolute recovery. This is in parallel with another research (Abe et al., 2008). Logistic regression analysis which done to assess factors predicting ICU admission, revealed that lower GCS and higher PSS were significantly accompanied by increased the likelihood of ICU admission. Furthermore, the ingested dose and the delay time since ingestion played a role. Abe et al. (2008) also designed various regression analyses to assess the length of hospital stay and the case severity; they reported that tachycardia, hypotension, leukocytosis and altered conscious level are parameters that prolong the hospital stay. This relative variation in the predicting factors might be due to including other psychotropic drugs in their research not a single class.

\section{Conclusion}

Severity of acute pediatric antipsychotic poisoning was higher during COVID 19 lockdown. Sinus tachycardia and prolonged QTc were the most predominant electrocardiographic changes. Lower GCS, higher PSS and prolonged delay time were bad prognostic values as well.

\section{Recommendations}

Suspected acute antipsychotic toxic ingestion should be treated in a poison control unit as early as possible to reduce complications with favorable prognosis. Campaigns on poison prevention policies should be directed to parents periodically. Antipsychotic drugs should be kept out of reach of children. Post COVID 19 studies are recommended for further evaluation. Multicenter studies are suggested for wider assessment of environmental and cultural factors affecting such poisoning.

\section{References}

Abe T, Tokuda Y, Stein GH, et al., (2008). Risk factors associated with prolonged hospital stay in admitted patients with psychotropic drug overdose. Open critical care medicine journal, 1: 12-16.

Akyol A, Senel AC, Ulusoy H, et al., (2005). Delayed respiratory depression after risperidone overdose. Anesthesia and analgesia, 101(5): 1490-1491.

Bond GR, Woodward RW and Ho M (2012). The growing impact of pediatric pharmaceutical poisoning. Journal of Pediatrics, 160: 265-270.

Borg L, Julkunen A, Rorbaek Madsen K, et al., (2016). Antidepressant or Antipsychotic overdose in the Intensive Care Unit- Identification of patients at risk. Basic clinical pharmacology toxicology, 119:110-4.

Ben-Noun LL (2000). Drug-induced respiratory disorders. Drug safety, 23(2):143-164.

Berling I, Buckley NA and Isbister GK (2016). The antipsychotic story: changes in prescriptions and overdose without better safety. British Journal of Clinical Pharmacology, 82: 249-54.

Capel MM, Colbridge MG and Henry JA (2000). Overdose profiles of new antipsychotic agents. Internationl Journal of Neuropsychopharmacology, 3(1):51-54.

Chohan PS, Mittal R and Javed A (2015). Antipsychotic medication and QT prolongation. Pakistan journal of medical sciences, 31(5): 1269-71.

Dayasiri MBKC, Jayamanne SF and Jayasinghe CY(2017). Risk Factors for Acute Unintentional Poisoning among Children Aged 1-5 Years in the Rural Community of Sri Lanka. International Journal of Pediatrics,2017: 9.

Divac N, Prostran M, Jakovcevski I et al., (2014). Second-generation antipsychotics and extrapyramidal adverse effects. BioMed research international, 2014: 656370..

DuBois D (2005). Toxicology and overdose of atypical antipsychotic medications in children: does new necessarily mean safer? Current Opinion in Pediatrics, 17(2): 227-33.

Fayed MM and Sherif AF (2021). Impact of Lockdown due to COVID-19 on the Modalities of Intoxicated Patients Presenting to the Emergency Room. Prehospital Disaster and Medicine,36(2):145-162.

Fehsel K, Loeffler S, Krieger K, et al., (2005). Clozapine induces oxidative stress and proapoptotic gene expression in neutrophils of schizophrenic patients. Journal of clinical psychopharmacology,25:419-426.

Georgiev K, Georgieva M, Marinov P et al., (2015). Acute poisonings with neuroleptics in clinic of toxicology of military medical academy 
Varna/Bulgaria registered for 20 year period. Scripta scientifica medica, 47:70-72.

Gugger JJ (2011). Antipsychotic pharmacotherapy and orthostatic hypotension. CNS drugs, 5(8):65971.

Gummin DD, Mowry JB, Spyker DA, et al., (2017). 2016 Annual Report of the American Association of Poison Control Centers' National Poison Data System (NPDS): 34th Annual Report. Clinical toxicology, 55: 1072-1254.

Gunarto H (2019). Parametric and Nonparametric Data Analysis for Social Research: IBM SPSS. LAP LAMBERT Academic Publishing.

Hammad S, Girgis N, Zaher Amin S, et al., (2016). Evaluation of acute antipsychotic poisoned cases. Menoufia Medical Journal, 29(4):11161121.

Jin Y-H, Cai L, Cheng Z-S, et al., (2020). A rapid advice guideline for the diagnosis and treatment of 2019 novel coronavirus (2019-nCoV) infected pneumonia. Military Medical Research, $7(1): 4$.

Kampf G, Todt D, Pfaender S et al., (2020). Persistence of coronaviruses on inanimate surfaces and their inactivation with biological agents. Journal of Hospital Infection; 104: 24651.

Kapur S and Seeman P (2000). Antipsychotic agents differ in how fast they come off the dopamine D2 receptors. Implications for atypical antipsychotic action. Journal of Psychiatry Neuroscience, 25(2):161-6.

Kramer I, Rauber-Luthy C, Kupferschmidt H, et al., (2010). Minimal dose for severe poisoning and influencing factors in acute human clozapine intoxication: a 13-year retrospective study. Clinical neuropharmacology,33(5): 230-234.

Kumra S, Oberstar JV, Sikich L, et al., (2008). Efficacy and tolerability of second-generation antipsychotics in children and adolescents with schizophrenia. Schizophrenia Bulletin, 34(1):60-71.

Levine $M$ and Burns MJ (2007). "Antipsychotic agents". In: Shannon MW, Borron SW, and Burns M (eds). Haddad and Winchester's clinical management of poisoning and drug overdose. 4th ed. Philadelphia: Saunders Elsevier. pp. 703-718.

Meli M, Rauber-Lüthy C, Hoffmann-Walbeck P, et al., (2014). Atypical antipsychotic poisoning in young children: a multicentre analysis of poisons centers data. European journal of pediatrics, 173(6):743-50.

Mubarak M, El-Madah E, El-Gharbawy D, et al. (2019). Assessment of acute antipsychotic poisoned cases admitted to Tanta University Poison Control Unit. Ain Shams J Forensic Med Clin Toxicol, 33:113-125.
Mucci N, Giorgi G, De Pasquale Ceratti S, et al., (2016). Anxiety, stress-related factors, and blood pressure in young adults. Frontiers in psychology, 7:1682.

Muench J and Hammer AM (2000). Adverse effects of antipsychotic medications. American Family Physicians,81(5):617-622.

Ngo A, Ciranni M and Olson KR (2008). Acute quetiapine overdose in adults: a 5-year retrospective case series. Annual Emergency Medicine, 52:541-7.

Pal A, Samanta S and Wig J (2015). Sustained ventricular tachycardia after electroconvulsive therapy: Can it be prevented? Indian journal of psychological medicine, 37(2): 247-248.

Persson HE, Sjo“berg GK, Haines JA, et al., (1998). Poisoning severity score. grading of acute poisoning. Journal of Clinical Toxicology, 36: 205-213.

Pickford M (2000). Antipsychotic drug overdose. Emergency nurse; 7(9):17-22.

Ramnarine M (2017). Anticholinergic Toxicity. Available on https://emedicine.medscape.com/article/812644overview.

Rasimas JJ and Liebelt EL (2012). Adverse effects and toxicity of the atypical antipsychotics: what is important for the pediatric emergency medicine practitioner. Clinical pediatric emergency medicine, 13(4): 300-310.

Roux GL and Tellier SS (2020). COVID-19: home poisoning throughout the containment period. Lancet Public Health, 5(6):314.

Sackey B, Miller LJ, and Davis MC (2017). Possible Clozapine Overdose-Associated Thromboembolic Event. Journal of clinical psychopharmacology, 37(3): 364-366.

Sheridan DC, Hendrickson RG, Lin AL, et al., (2017). Adolescent suicidal ingestion: national trends over a decade. Journal of adolescent health, 60(2): 191-195.

Tan HH, Hoppe J and Heard K (2009). A systematic review of cardiovascular effects following atypical antipsychotic medication overdose. The American journal of emergency medicine,27(5): 607-616.

Ucok ALP and Gaebel W (2008). Side effects of atypical antipsychotics: a brief overview. World Psychiatry, 7(1): 58-62.

Watson WA, Litovitz TL, Rodgers GC, et al., (2004). Annual report of the American Association of Poison Control Centers Toxic Exposure Surveillance System. The American Journal of Emergency Medicine, 23(5):589-666.

Wenzel-Seifert K, Wittmann M and Haen E (2011). QTc prolongation by psychotropic drugs and the risk of Torsade de Pointes. Deutsches Ärzteblatt International, 108: 687-693. 


\title{
تأثير الإغلاق بسبب كوفيد ـ9 19 على نتائج التسمم الحاد بمضادات الذهان لاى الأطفال في مركز جامعه طنطا
} لعلاج حالات التسمم

\author{
نادية عزت هلال', السيد ابراهيم الجبالي', دينا الجميل الجميل' \\ الملخص العربى
}

المقدمة: إن حالات التسمم الحاد بمضادات الذهان لدى الأطفال قد زادت بشكل ملحوظ خلال فترة الإغلاق الناتج عن كوفيد 9 ـ نم إجر اء الحد الأدنى من الأبحاث المتعلقة بهذا الموضوع في مصر.

الههف: تهدف الدراسة الحالية الى تحديد متنبئات نتائج التسمم الحاد بمضادات الذهان لاى الأطفال أثناء الإغلاق الناتج عن كوفيد

طرق البحث: أجريت الدر اسة على الأطفال المصابين بالتسمم الحاد بمضادات الذهان و و الذين تم إدخالهم ب مركز جامعه طنطا

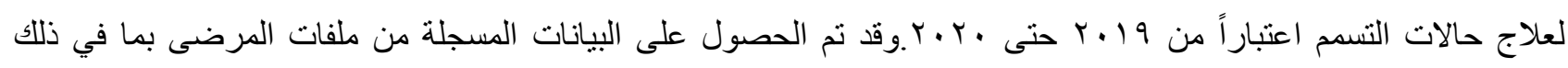
الخصائص الاجتماعية الديمو غر افية والفحص السريري ونتائج الفحوصات المختبرية وتخطيط القلب بالإضافة إلى تقييم الثدة عن

طريق مقياس درجة شدة السمية

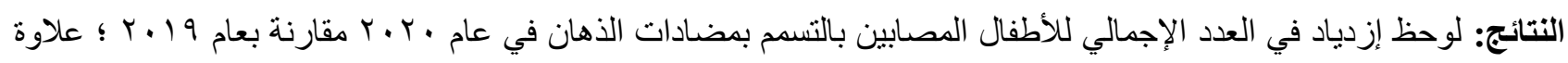
على ذللك ، إزدادت كميه الجر عات المبتلعة ومعدلات الانتحار ومنوسط وقت التأخير لحين دخول بالمستشفي في عام • ب . r وكانت

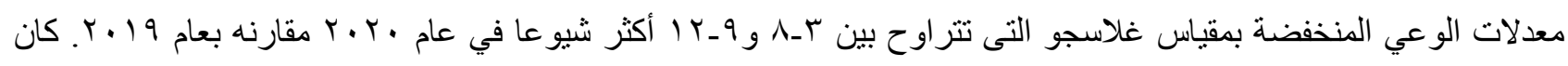
معدل التسمم بمضادات الذهان الغير تقليديه ذات الحد الأدنى من المظاهر خارج الهرمية هو الأكثر شيوعًا في هذه الدراسة .كان انخفاض ضغط الدم وتغيرات تخطيط القلب خاصة تسرع القلب الجيبي وفترات كيو-نى المصححة المطولة شائعاً في العينة

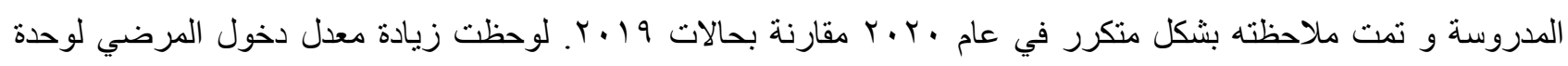

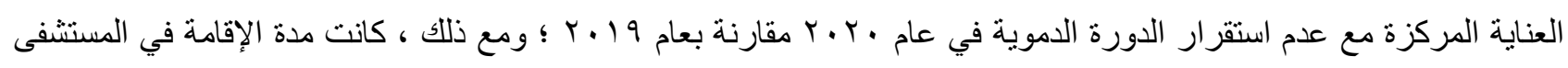
متساوية تقريبًا. تم إجر اء تحليل الانحدار اللوجستي، وكثف أن انخفاض مستوى الوعي بمقياس غلاسجو و مقياس شده السميه الأعلى كانا مصحو بين بشكل كبير بزيادة احتمال دخول وحدة العناية المركزة.

الاستنتاج: كانت شدة التسمم بمضادات الذهان أعلى خلال إغلاق كوفيد 19 وقد تم التوصل إلى تنبؤات للنتائج الأسوأ فيما يتعلق بمعدلات القبول في وحدة العناية المركزة و السمية العصبية والقلبية الوعائية. 